Open Access

Res. Agric. Livest. Fish.

Research Article

Vol. 2, No. 1, April 2015: 169-175

\title{
COMPARATIVE STUDY ON GROWTH OF SUPERMALE TILAPIA AND MONOSEX TILAPIA IN EARTHEN MINI POND
}

\section{Gias Uddin Ahmed, Habiba Aktar, Sudristi Chakma, Neaz Al Hasan and Mohammad Shamsuddin}

Department of Aquaculture, Faculty of Fisheries, Bangladesh Agricultural University, Mymensingh-2202, Bangladesh

*Corresponding author: Gias Uddin Ahmed; E-mail: giasa50@gmail.com

\begin{tabular}{|c|c|}
\hline ARTICLE INFO & ABSTRACT \\
\hline $\begin{array}{l}\text { Received } \\
13.02 .2015 \\
\text { Accepted } \\
\text { 12.04.2015 } \\
\text { Online } \\
\text { 19.04.2015 } \\
\text { Key words } \\
\text { Growth } \\
\text { Monosex } \\
\text { Supermale } \\
\text { Tilapia } \\
\text { Mini pond }\end{array}$ & $\begin{array}{l}\text { An investigation was conducted to determine the comparative growth study of } \\
\text { supermale tilapia and monosex tilapia in earthen mini ponds from May-J uly } 2012 \text {. } \\
\text { Four treatments were considered having two replicates. For supermale tilapia } \\
\text { treatments were named as } \mathrm{ST}_{1} \text { and } \mathrm{ST}_{2} \text { and for monosex tilapia were } \mathrm{MT}_{1} \text { and } \mathrm{MT}_{2} \text {. } \\
\text { All the fish were of same age group having mean body weight of } 1.4 \mathrm{~g} \text {. Feeding } \\
\text { frequency in all the treatments were two times a day. Fish were fed diet at a rate of } \\
30 \% \text { of their body weight for the first thirty days that was gradually reduced to } 15 \% \\
\text { for the next thirty days and } 5 \% \text { till the termination of the experiment. Final weight, } \\
\text { weight gain, average daily weight gain, } \% \text { weight gain and production of supermale } \\
\text { tilapia were significantly ( } \mathrm{p}<0.05 \text { ) higher than those of monosex tilapia. But } \mathrm{SGR} \text { (\% } \\
\text { day), FCR and survival rate of supermale tilapia were not significantly (p>0.05) } \\
\text { varied. However, the result of the present study showed that the best weight gain of } \\
124.85 \mathrm{~g} \text { was observed in } \mathrm{ST}_{1} \text { after } 90 \text { days culture period. Average weight gain ( } \mathrm{g} \text { ) } \\
\text { were } 1.39,1.16,1.14 \text { and } 1.05, \mathrm{SGR} \text { (per day) were } 2.17,2.09,2.08 \text { and } 2.04 \%, \mathrm{FCR} \\
\text { were } 2.98,2.65,2.84 \text { and } 2.57, \text { survival rate were } 96,94.50,95 \text { and } 91 \% \text { and fish } \\
\text { production were } 5053.92,8926.10,4108.07 \text { and } 7821.41 \mathrm{~kg} / \text { ha in } \mathrm{ST}_{1}, \mathrm{ST}_{2}, \mathrm{MT}_{1} \text { and } \\
\text { MT2 respectively. The present research findings suggested that supermale tilapia has } \\
\text { significantly high growth potential compare to monosex tilapia under mini ponds } \\
\text { culture condition. }\end{array}$ \\
\hline
\end{tabular}

To cite this article: GU Ahmed, H Aktar, S Chakma, NA Hasan and M Shamsuddin. 2015. Comparative study on growth of supermale tilapia and monosex tilapia in earthen mini pond. Res. Agric. Livest. Fish. 2 (1): 169-175. 


\section{INTRUDUCTION}

Tilapia is known to be an important of subsistence fisheries for thousands of years but have gained prominence in recent years. Tilapia, that is native to Africa and Middle East, has emerged from mere obscurity to one of the most productive and internationally traded food fish in the world. The introduction of the tilapia in Bangladesh from Thailand was first initiated in 1954 with Tilapia mossambica (Ahmed, 1956) and later in 1974, high yielding species of tilapia (Oreochromis niloticus) was introduced by UNICEF (Rahman, 1985) with a hope that it would make a significant contribution to fish production. Orechromis niloticus has for many decades, been responsible for the significant increase in global tilapia production from freshwater aquaculture and accounted for about $83 \%$ of total tilapias produced worldwide (FAO, 2002). Monosex tilapia (Oreochromis nloticus) newly introduced as exotic species in aquaculture system of Bangladesh (FAO, 1999).

Many potential rural fish farmers and pond owners of Bangladesh are poor and they do not have the capability to invest much money for purchasing fish seed, fertilizer and feed. As a result their ponds remained derelict. The Department of Fisheries (DoF, 1993) estimated about $17 \%$ of derelict ponds or ditches in Bangladesh, which are lying fallow, expect some used for catching wild fishes only. These derelict ditches retain water for 4-6 months and can be utilized properly by culturing short cycle species like monosex tilapia (Orechromis niloticus). In Bangladesh aquaculture is the most promising option for increasing fish production. Monosex tilapia is the best candidate to overcome this situation due to its desirable characteristics such as males are used for monosex culture grows faster than females (Popma and Lovshin, 1996). Male monosex culture permits the use of longer culture periods, higher stocking rates and fingerlings of any age. Monosex tilapia has good resistance to poor water quality, disease and tolerance to a wide range of environmental conditions.

Monosex tilapia is a fast growing popular cultivable fish (Chowdhury et al., 1991). In Bangladesh, commercial farming of tilapia has been found to develop rapidly since the introduction of Genetically Improved Farmed Tilapia (GIFT) from the Philippines in 1994 (Alam and Kawsar, 1998). The success of using the GIFT strain of tilapia for commercial farming is due to its ability to produce millions of monosex male fry in hatcheries and this practice has been found to considerably eliminate the problems related to the production of mixed sex tilapia showing slow growth as well as the production of small-sized individuals in a given culture facility (Mair and Little, 1991). Recently farmers of Mymensingh region introduced supermale (YY male) tilapia through genetic manipulation (Haque, 2012 personal communication). It is thus important to investigate the culture potential of this tilapia and compare with the growth of monosex tilapia. Therefore, the present experiment has been designed to study culture potential and growth variation of supermale tilapia with those of monosex tilapia and culture feasibility of supermale tilapia in earthen mini ponds.

\section{MATERIALS AND METHODS}

The experiment was conducted in eight experimental pond each of 0.65 dec which were located in the northern side of the Faculty of Fisheries, Bangladesh Agricultural University, Mymensingh. The study period was carried out for 90 days from 03 May to 31 July, 2012. The water depth was maintained at a level of 1.0 to $1.3 \mathrm{~m}$. The ponds were equal in size and similar in shape, depth, basin configuration and pattern type including water supply facilities. Aquatic weeds, undesirable fishes, insects and other aquatic organisms were removed manually and the grasses on the pond dykes were also pruned manually into very small size. Lime was applied at a rate of $0.5 \mathrm{~kg} / \mathrm{dec}$. No fertilizer was used during pond preparation.

Two treatments were considered for supermale tilapia and two treatments for monosex tilapia. In each treatment two replications were considered. Monosex tilapia fry were collected from Sarnalata Agro Fisheries Ltd., Radhakanai, Fulbaria, Mymensingh and super male tilapia fry were collected from the Brahmaputra Hatchery, Shamvuganj, Mymensingh. Fry were transported by plastic drums having oxygen facilities and transferred to ponds. During stocking sufficient care was taken to reduce stress. Commercial pellet feed named "Quality Fish Feed" were selected for the study. At the beginning of the experiment feed was supplied at a rate of $30 \%$ (1st month) of their body weight, $15 \%$ (2nd month), $5 \%$ up to harvesting time. Half of the feed was supplied at 9:00 AM and remaining was supplied at about 5:00 PM. 
The feed was supplied by spreading method. The experimental ponds were monitored everyday during feeding to observe the behavior of fishes. All the ponds were kept clean to provide hygienic condition. Water quality parameters such as temperature $\left({ }^{\circ} \mathrm{C}\right)$, dissolved oxygen $(\mathrm{mg} / \mathrm{l}), \mathrm{pH}$ and ammonia $(\mathrm{mg} / \mathrm{l})$ were recorded fortnightly. Parameters such as weight gain (g), average daily weight gain (g), percent weight gain, specific growth rate (SGR), food conversion ratio (FCR), survival rate (\%) and production ( $\mathrm{kg} / \mathrm{ha} / \mathrm{yr}$ ) were calculated to evaluate the growth performances of fish. Fish sampling was done at fifteen days interval in the morning at around 7:30 AM to 8:30 AM. During each sampling, fish were caught by cast net and weight was taken by precision weighing balance. Data were kept for analysis of different parameters.

\section{RESULTS AND DISCUSSION}

The mean initial weight of supermale tilapia and monosex tilapia in both the treatments was $1.4 \mathrm{~g}$. Mean weight gains of supermale at the end of the experiment were $124.85 \mathrm{~g}$ and $104.35 \mathrm{~g}$ and monosex tilapia were 102.35 and $94.45 \mathrm{~g}$ in $\mathrm{T}_{1}$ and $\mathrm{T}_{2}$ respectively (Table 1 and Fig. 1).

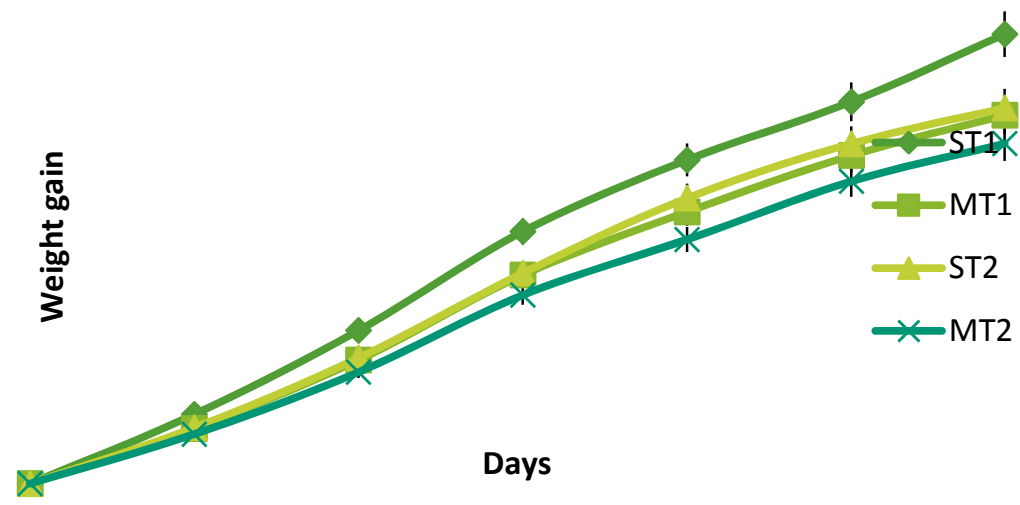

Figure 1. Mean weight gain of both tilapia in both treatments during the experimental Period

Average daily weight gain of supermale and monosex tilapia at the end of the experiment was followed by 1.39, 1.16, 1.14 and $1.05 \mathrm{~g}$ in $\mathrm{ST}_{1}, \mathrm{ST}_{2}, \mathrm{MT}_{1}$ and $\mathrm{MT}_{2}$, respectively. Mean weight gain of monosex tilapia for 90 days experiment were 102.359 and $94.45 \mathrm{~g}$ in $T_{1}$ and $T_{2}$, respectively. The percent weight gain of supermale tilapia till the end of the experiment were 8917.86 and 7453.57 in $T_{1}$ and and $T_{2}$, repectively (Table 1). In monosex tilapia the percent weight gain was 7310.71 and 6746.43 in $T_{1}$ and $T_{2}$, respectively. During the investigation of 90 days specific growth rate (SGR) in $\mathrm{T}_{1}$ of supermale and monosex were $2.17 \%$ and $2.08 \%$ (Table 1). In $T_{2}$ of supermale and monosex tilapia the values were $2.09 \%$ and $2.04 \%$ respectively (Table 1 ). The mean values of FCR for supermale in $T_{1}$ and $T_{2}$ were 2.98 and 2.65 respectively (Table 1). In case of monosex tilapia, the mean values of FCR were 2.84 and 2.57 respectively (Table 1 ). The survivals of fish at the end of the experiment were $96 \pm 1.00,94.5 \pm 0.50,95 \pm 1.00$ and $91 \pm 1.00$ in $\mathrm{ST}_{1}, \mathrm{ST}_{2}, \mathrm{MT}_{1}$ and $\mathrm{MT}_{2}$ respectively. Higher survival rate were obtained in $\mathrm{ST}_{1}(96 \%)$ and lower was in $\mathrm{MT}_{2}$ (91\%) (Table 1). Production of supermale tilapia in $T_{1}$ and $T_{2}$ was $5063.916 \mathrm{~kg} / \mathrm{ha}$ and $8926.099 \mathrm{~kg} / \mathrm{ha}$ and production of monosex tilapia in $\mathrm{T}_{1}$ and $\mathrm{T}_{2}$ were $4108.072 \mathrm{~kg} / \mathrm{ha}$ and $7821.405 \mathrm{~kg} / \mathrm{ha}$ respectively (Table 1 ).

The range of water temperature were 28.25 to $30^{\circ} \mathrm{C}$ in $\mathrm{ST}_{1}, 28.63$ to $31.25^{\circ} \mathrm{C}$ in $\mathrm{ST}_{2}, 28.13$ to $31.75^{\circ} \mathrm{C}$ in $\mathrm{MT}_{1}$ and 28.33 to $30.25^{\circ} \mathrm{C}$ in $\mathrm{MT}_{2}$. Range of dissolved oxygen values were 6.5 to $8 \mathrm{mg} / \mathrm{l}, 7$ to $8 \mathrm{mg} / \mathrm{l}, 6.5$ to $7.65 \mathrm{mg} / \mathrm{l}$ and 6.5 to $8 \mathrm{mg} / \mathrm{l}$ in $\mathrm{ST}_{1}, \mathrm{ST}_{2}, \mathrm{MT}_{1}$, and $\mathrm{MT}_{2}$. The range of $\mathrm{pH}$ values were recorded from 7.25 to 7.75 in $\mathrm{ST}_{1}, 7.25$ to 7.38 in $\mathrm{ST}_{2}, 7.25$ to 7.88 in $\mathrm{MT}_{1}$ and 7.08 to 7.88 . The ammonia content of the experiment was varied from 0.15 to $0.25 \mathrm{mg} / \mathrm{l}$ in $\mathrm{ST}_{1}, 0.18$ to $0.30 \mathrm{mg} / \mathrm{l}$ in $\mathrm{ST}_{2}, 0.18$ to $0.33 \mathrm{mg} / \mathrm{l}$ in $\mathrm{MT}_{1}$ and 0.20 to 0.25 $\mathrm{mg} / \mathrm{l}$ in $\mathrm{MT}_{2}$. 


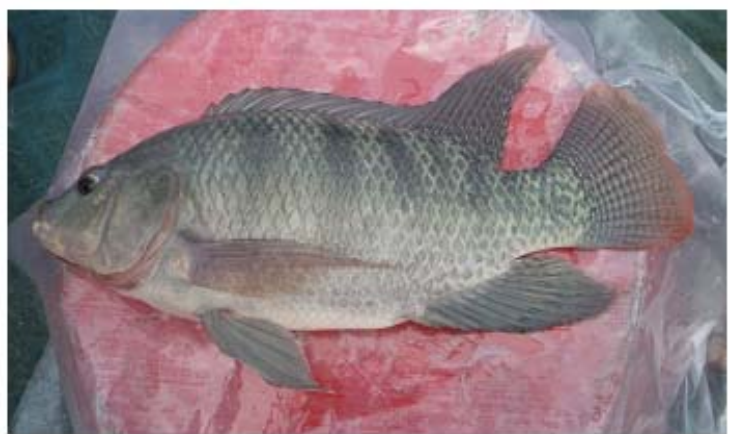

Figure 2. Supermale Tilapia

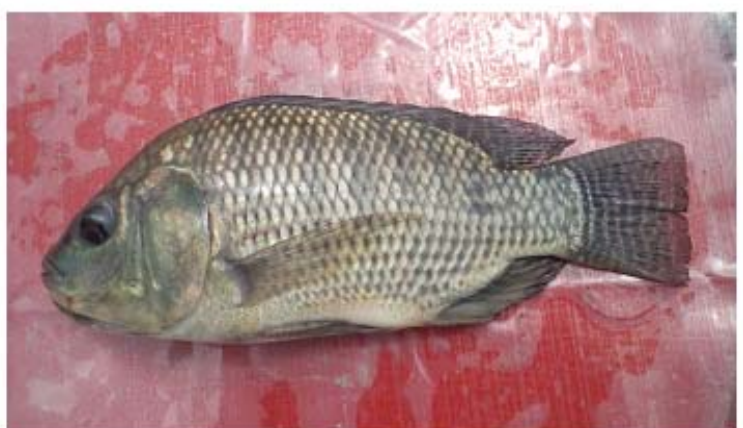

Figure 3. Monosex Tilapia

Table 1. Growth parameters of supermale and monosex tilapia in $\mathrm{ST}_{1}$ and $\mathrm{MT}_{1}$ during the study period

\begin{tabular}{|lllll|}
\hline Growth parameters & $\begin{array}{c}\text { Supermale Tilapia } \\
\mathbf{S T}_{\mathbf{1}}\end{array}$ & \multicolumn{1}{c}{$\begin{array}{c}\text { Monosex Tilapia } \\
\mathbf{M T}_{\mathbf{1}}\end{array}$} & \multicolumn{1}{c}{$\begin{array}{c}\text { Supermale Tilapia } \\
\mathbf{S T}_{2}\end{array}$} & $\begin{array}{c}\text { Monosex Tilapia } \\
\mathbf{M T}_{\mathbf{2}}\end{array}$ \\
\hline Mean initial weight (g) & $1.40 \pm 0.09^{\mathrm{a}}$ & $1.40 \pm 0.09^{\mathrm{a}}$ & $1.40 \pm 0.09^{\mathrm{a}}$ & $1.40 \pm 0.09^{\mathrm{a}}$ \\
Mean final weight (g) & $126.25 \pm 4.41^{\mathrm{a}}$ & $103.75 \pm 3.42^{\mathrm{b}}$ & $105.75 \pm 4.06^{\mathrm{b}}$ & $95.85 \pm 4.35^{\mathrm{c}}$ \\
Mean weight gain (g) & $124.85 \pm 12.29^{\mathrm{a}}$ & $102.35 \pm 4.76^{\mathrm{b}}$ & $104.35 \pm 6.77^{\mathrm{b}}$ & $94.45 \pm 6.37^{\mathrm{c}}$ \\
Av. daily weight gain (g) & $1.39 \pm 0.14^{\mathrm{a}}$ & $1.14 \pm 0.05^{\mathrm{b}}$ & $1.16 \pm 0.08^{\mathrm{b}}$ & $1.05 \pm 0.07^{\mathrm{c}}$ \\
\% weight gain & $8917.86 \pm 877.61^{\mathrm{a}}$ & $7310.71 \pm 340.30^{\mathrm{b}}$ & $7453.57 \pm 483.58^{\mathrm{b}}$ & $6746.43 \pm 454.93^{\mathrm{c}}$ \\
SGR (\%/day) & $2.17 \pm 0.05^{\mathrm{a}}$ & $2.08 \pm 0.02^{\mathrm{a}}$ & $2.09 \pm 0.03^{\mathrm{a}}$ & $2.04 \pm 0.04^{\mathrm{a}}$ \\
FCR & $2.98 \pm 0.57^{\mathrm{a}}$ & $2.84 \pm 0.83^{\mathrm{a}}$ & $2.65 \pm 0.19^{\mathrm{a}}$ & $2.57 \pm 0.83^{\mathrm{a}}$ \\
Survival rate & $96.00 \pm 1.00^{\mathrm{a}}$ & $95.00 \pm 1.00^{\mathrm{a}}$ & $94.50 \pm 0.50^{\mathrm{a}}$ & $91.00 \pm 1.00^{\mathrm{a}}$ \\
Production & $5063.916 \mathrm{~kg} / \mathrm{ha}^{\mathrm{a}}$ & $4108.072 \mathrm{~kg} / \mathrm{ha}^{\mathrm{b}}$ & $8926.099 \mathrm{~kg} / \mathrm{ha}^{\mathrm{c}}$ & $7821.405 \mathrm{~kg}^{\mathrm{h}} \mathrm{ha}^{\mathrm{d}}$ \\
\hline
\end{tabular}

*Superscripts in each row with different letter significantly $(P<0.05)$ different

In the present study the highest of weight gain significantly $(p<0.05)$ higher was found in $T_{1}(124.85 \mathrm{~g})$ of supermale tilapia whereas, the lowest weight gain was found from the $T_{2}(94.45 \mathrm{~g})$ of monosex tilapia. Also from $T_{2}$ of supermale, final weight was found significantly $(p<0.05)$ higher $(104.35 \mathrm{~g})$ when compared with $T_{1}$ $(102.35 \mathrm{~g})$ and $\mathrm{T}_{2}(94.45 \mathrm{~g})$ of monosex tilapia. The results indicated that the growth rate of supermale tilapia was higher than monosex tilapia. Supermale tilapia had been reported to grow faster than the mixed-sex tilapia or the monosex tilapia obtained from the conventional hormone induction method (Mair and Little, 1991; Rahman and Sarder 2010). Ahmed et al. (2013) obtained a weight gain of $123.48 \mathrm{~g}$ and $111.82 \mathrm{~g}$ from two different treatment of monosex tilapia for a period of 70 days which were higher than the values obtained from the present investigation. The results of the present experiment showed that the growth rate of tilapia in both the variety were higher in lower stocking densities. Begum (2009) obtained $47.03 \mathrm{~g}$ and $39.93 \mathrm{~g}$ of monosex tilapia at stocking densities of $200 \mathrm{fish} / \mathrm{dec}$ and $300 \mathrm{fish} / \mathrm{dec}$ respectively which were much lower than the value obtained in the present study. It was observed in the present experiment that the highest mean weight gain $(124.85 \mathrm{~g})$ of fish was in $\mathrm{ST}_{1}$ stocked at lower densities, although, same feed and feeding rate were applied in all the treatments. The mean lowest weight gain $(94.45 \mathrm{~g})$ obtained in the present experiment under the highest stoking rate of 200/dec in $\mathrm{MT}_{2}$. Kohinoor et al. (1998) found the highest growth of tilapia stocked at the rate of $80 \mathrm{fish} / \mathrm{dec}$ which were much lower than the value obtained in the present investigation. At the end of the experiment the highest average daily weight gain was in $\mathrm{ST}_{1}(1.39 \mathrm{~g} / \mathrm{day})$ and the lowest average daily weight gain was in $\mathrm{MT}_{2}$ (1.05 g/day). According to Rasel (2012) the recorded mean average daily weight gain was $0.0049 \mathrm{~g} / \mathrm{day}, 0.0062 \mathrm{~g} /$ day and $0.0073 \mathrm{~g} /$ day during the rearing of fry of monosex tilapia in three different treatments for 100 days which were lower than present findings. From the research findings of Das (2007) it was observed that the highest average daily weight gain was $1.94 \mathrm{~g} / \mathrm{day}$ for Oreochromis niloticus fed on formulated diet which were higher than the values obtained in the present study. 
From the investigation the highest mean percent weight gain $(8917.86 \mathrm{~g})$ was found from the $\mathrm{ST}_{1}$ compared to $\mathrm{ST}_{2}(7453.57 \mathrm{~g}), \mathrm{MT}_{1}(7310.71 \mathrm{~g})$ and $\mathrm{MT}_{2}(6746.43 \mathrm{~g})$. This might be due to less competition for feed in lower stocking density and also for higher growth rate of supermale tilapia. From the research findings of Ahmed et al. (2013) it could be mentioned that percent weight gain for monosex tilapia were $123348.44 \mathrm{~g}$ and $11181.78 \mathrm{~g}$ in $\mathrm{T}_{1}$ and $\mathrm{T}_{2}$ respectively which were higher than present findings. Begum (2009) found the highest mean percent weight gain for monosex tilapia was $9406 \mathrm{~g}$ and $7986 \mathrm{~g}$ for four months culture period in $\mathrm{T}_{1}$ and $\mathrm{T}_{2}$ respectively which has similarity with the present findings.

The result of the present experiment revealed that values of SGR of supermale were $2.17 \%$ in $\mathrm{T}_{1}$ and $2.09 \%$ in $\mathrm{T}_{2}$. In monosex tilapia SGR values were $2.08 \%$ and $2.04 \%$ in $\mathrm{T}_{1}$ and $\mathrm{T}_{2}$ respectively. Higher values of SGR were obtained from ST1 and $\mathrm{MT}_{1}$ which had lower stocking densities. Islam (2007) and Alam (2009) obtained the highest values of SGR at the lowest stocking densities which coincide with the present findings. According to Mamun et al. (2010), Genetically Male Tilapia and Sex Reversed Tilapia were grown in six earthen ponds and found SGR values as $0.997 \%$ and $0.988 \%$ respectively, which were much lower than the value obtained in the present investigation. Hossain et al. (2004) observed SGR values of tilapia were ranged from 2.04 to 2.30 fed on formulated diet that has similarity with the findings of present study. In the present investigation FCR were varied from 2.98 to 2.57 .

FCR values for supermale tilapia in $T_{1}$ and $T_{2}$ were 2.98 and 2.65 respectively, whereas, for monosex tilapia in $T_{1}$ and $T_{2}$ were 2.57 and 2.84 respectively. From the research finding of Ahmed et al. (2013) it was observed that FCR values for monosex tilapia fed on homemade feed were 1.51 and 1.40 in $T_{1}$ and $T_{2}$ respectively. Hossain et al. (2004) investigated FCR of gift strain of tilapia fed on formulated diet (30.09\% protein) was 1.71 and 1.77 which was lower than present results. The fishes might have properly utilized most of the formulated feed and the utilized feed help in production of supermale and monosex tilapia in the present study.

In the present experiment the highest survival rate was recorded in $T_{1}$ of supermale tilapia and the lowest survival rate in $\mathrm{T}_{2}$ of monosex tilapia. Kohinoor et al. (2007) observed survival rates of monosex tilapia were varied from $79 \%$ to $92 \%$. According to Ahmed et al. (2013) survival rate of monosex tilapia were $75.55 \%$ and $90.37 \%$ in $T_{1}$ and $T_{2}$ respectively during the harvesting time which has similarity with the survival rate of present experiment. Survival rate was found to be negatively influenced by different stocking densities such as the lowest stocking density showed the highest survival rate which might be due to high competition of food and space among the fishes.

The productions of supermale and monosex tilapia were $5053.92 \mathrm{~kg}, 8926.1 \mathrm{~kg}, 4108.07 \mathrm{~kg}$ and 7821.41 $\mathrm{kg}$ in $\mathrm{ST}_{1}, \mathrm{ST}_{2}, \mathrm{MT}_{1}$ and $\mathrm{MT}_{2}$ respectively. Although mean weight gain was found higher in $\mathrm{ST}_{1}$ but total production was higher in $\mathrm{ST}_{2}$ which might be due to higher number of fishes. The present result supports the findings of Roy (2002) who achieved the best production from higher stocking densities in comparison with that achieved with the lower ones. Ahmed et al. (2013) mentioned that average yield of monosex tilapia were $19076 \mathrm{~kg} / \mathrm{ha}$ and $16312.11 \mathrm{~kg} / \mathrm{ha}$ in two different treatments with same stocking densities fed with homemade feed and formulated feed in earthen mini pond. Begum (2009) observed the highest production was 9.63 $\mathrm{kg} / \mathrm{dec} / 120$ days whereas Das (2007) found total production was $34.04 \mathrm{~kg} / \mathrm{dec} / 90$ days for monosex tilapia.

A simple economic analysis of the growth performance of fish showed that the highest net profit ( $T k /$ ha/year) of Tk 9,56,685 was obtained with $\mathrm{ST}_{2}$. The highest net profit in $\mathrm{ST}_{2}$ was due to high growth rate and density tolerance of supermale tilapia compared to monosex tilapia. Das (2007) mentioned that the net profit of Oreochomis niloticus was 3,87,716 Tk/ha/year using formulated diet which were much lower than the value obtained in the present investigation. According to Chakma (2011) net benefit were 2,07,328.53 $\mathrm{Tk} / \mathrm{ha} / 70$ days and $77,917 \mathrm{Tk} / \mathrm{ha} / 70$ days.

Culture of monosex tilapia bears high production potential in Bangladesh. A number of hatcheries are producing monosex male fry through androgenic hormone feeding, but a considerable percentage of female fry in each batch has been reported. Supermale tilapia can eliminates the customers concern on residual hormonal health hazard. From the experiment it was found that supermale had high growth rate and density tolerance compare to monosex tilapia. Supermale tilapia has nice reddish color and shape is slightly round which attract the customer's attention. During the economic analysis it was found that the net profit from the present experiment might be due to higher mean increased weight of supermale tilapia. So it can be brought to a conclusion that the supermale tilapia has high growth potential in comparison with monosex tilapia. 
Proper training on culture of this new variety on mini ponds could help in poverty alleviation at rural farmer's level. Income of the rural poor farmers could be increased through derelict household mini ponds brought under cultivation. All family members especially women can take participation in supermale tilapia culture and could contribute to family income.

\section{REFERENCES}

1. Ahmed GU, N Sultana, M Shamsuddin and MB Hossain, 2013. Growth and Production Performance of Monosex Tilapia (Oreochromis niloticus) Fed with Homemade Feed in Earthen Mini Ponds. Pakistan Journal of Biological Sciences, 1-5.

2. Ahmed M, 1956. Transplantation of fish food to East Pakistan. Pakistan Journal of Science, 8: 167170.

3. Alam MN, 2009. Effects of stocking density on the growth and survival of monosex male tilapia (Oreochromis niloticus) fry (GIFT Strain) in hapa, MS Thesis, Department of Aquaculture, Bangladesh Agricultural University, Mymensingh. pp. 40.

4. Alam SM and MA Kawsar, 1998. Effect of estrogens on growth and sex-ratio in the genetically imporved farmed tilapia, Oreochromis niloticus (L.). Bangladesh Journal of Zoology, 26: 37-43.

5. Begum M, 2009. Effects of stocking density on the growth and production performance of monosex tilapia, MS Thesis, Department of Aquaculture, Bangladesh Agricultural University, Mymensingh. pp. 31.

6. Chakma A, 2011. Growth performance of Thai pangus (Pangasianodon hypophthalmus) using prepared and commercial feed, MS, Thesis, Department of Aquaculture, Bangladesh Agricultural University, Mymensingh. pp. 49.

7. Chowdhury MBR, MM Muniruzzaman and N Uddin, 1991. Studies on the intestinal bacteria; flora of tilapia, Oreochromis niloticus. Bangladesh Journal of Aquaculture, 11: 23-25.

8. Das R, 2007. Effect of stocking density on the growth, survival and production of monosex male tilapia (Oreochromis niloticus) fed on formulated diet, MS Thesis, Department of Aquaculture, Bangladesh Agricultural University, Mymensingh. pp. 77.

9. DoF, 1993. Fish catch statistics of Bangladesh. 1992-93. Department of Fisheries, Dhaka, Bangladesh. (BGP-94/95-5177B-1000-24-7-95).

10. FAO, 1999. Fisheries Statistics, Capture Production. Food and Agriculture Organization of the United Nations (FAO), Rome. pp. 703.

11. FAO, 2002. Fishery Statistics. Aquaculture production, 90(2).

12. Hossain MA, R Roy, SM Rahmatullah and AHM Kohinoor, 2004. Effect of stocking density on the growth and survival of GIFT tilapia, (O. niloticus) fed on formulated diet. Journal of Agriculture and Rural Development, 2: 127-133.

13. Haque MN, 2012. Supermale (YY) tilapia. Owner of Brahmaputra Hatchery, Shamvuganj, Mymensingh.

14. Islam MS, 2007. Effects of stocking density on the growth and production performance of Tilapia (Oreochromis niloticus) in ponds, MS Thesis, Department of Aquaculture, Bangladesh Agricultural University, Mymensingh. pp. 54.

15. Kohinoor AHM, AKMS Islam, DA Jahan, M Zakir and MG Hussain, 2007. Monoculture of climbing perch, Thai koi, (Anabas testudineus) (Bloch) under different stocking densities at on farm. Bangladesh Journal of Fisheries Research, 11: 173-180

16. Kohinoor AHM, PC Modak and MG Hussain, 1998. Growth and production performance of red tilapia and Nile tilapia under low input culture system. Bangladesh Journal of Fisheries Research, 3: 11-17.

17. Mair GC and DC Little 1991.Population control in farmed tilapia, Naga, ICLARM Quarterly. pp. 8-13.

18. Mamun AA, MRI Sarder and MM Rahman, 2010. Growth performance of genetically male (GMT) and hormone induce sex reversed male tilapia (Oreochromis niloticus, L.) in earthen pond aquaculture system. Bangladesh Journal of Zoology, 38: 163-169. 
19. Popma TJ and LL Lovshin, 1996. Worldwide prospects for commercial production. Research and Development Series No. 41. Department of Fisheries and Allied Aquaculture, Auburn University, Alabama, USA. pp. 23.

20. Rasel M, 2012. Studies on brood rearing fry production and nursing of monosex tilapia, MS Thesis, Department of Aquaculture, Bangladesh Agricultural University, Mymensingh. pp. 50.

21. Rahman MM and MRI Sardar, 2010. Production of Hormone-induced Supermale of Genetically Improved Farmed Tilapia (GIFT-YY) in Bangladesh. Asian Fisheries Science, 23: 136-144.

22. Rahman AKA, 1985. Introduction of exotic fishes in Bangladesh. Paper presented in the seminar on culture of exotic fish in Bangladesh. October 15, 1989. Bangladesh Zoological Society. Dhaka University, Dhaka, 14.

23. Roy R, 2002. Effect of stocking density on the growth and survival of GIFT tilapia fed on formulated diet. MS Thesis, Department of Aquaculture, Bangladesh Agricultural University, Mymensingh. pp. 63. 